\title{
ECOLOGICAL RATIONAL WAYS OF TECHNOGENIC REHABILITATION OF TILIGUL LYMAN
}

\section{ЕКОЛОГО-РАЦІОНАЛЬНІ ШЛЯХИ ТЕХНОГЕННОГО ВІДНОВЛЕННЯ ТИЛІГУЛЬСЬКОГО ЛИМАНУ}

\author{
Igor V. Nakonechniy \\ nakonechniigor777@gmail.com \\ ORCID: 0000-0002-3797-3725 \\ Ganna G. Trokhymenko \\ antr@ukr.net \\ ORCID: 0000-0002-0835-3551 \\ Serhii M. Litvak \\ piskyn@mksat.net \\ ORCID: 0000-0002-1508-8493
}

\author{
I. В. Наконечний, \\ докт. біол. наук, професор \\ Г. Г. Трохименко, \\ докт. техн. наук, професор \\ С. М. Літвак, \\ канд. техн. наук, професор
}

\author{
Admiral Makarov National University of Shipbuilding, Mykolaiv \\ Національний університет кораблебудування імені адмірала Макарова, м. Миколаїв
}

\begin{abstract}
The Tiligul estuary is one of the largest estuaries of the Northern Black Sea coast, which, in conditions of climate change, has practically lost its ability to self-restoring water balance. Despite the two-year period of seawater submission through the rehabilitated "Sea - Estuary" Channel, the level of modern salinity of its waters (19...23...26\%o) significantly increases in the summer (to $27 . .28 \%$ ) and almost doubles the salinity of the Black Sea waters (16...17\%o) The excessive salinity of the estuary, especially in its lower part, is the main cause of the emergence and sustained maintenance of thermo- and halocline, which in turn leads to the formation of non-oxygen "dead" zones at depths greater than $4 \mathrm{~m}$. Materials of long-term environmental and hydrological studies of the Tiligul estuary allow to justify and to propose a partial regulated use of the Dnieper-Bug estuary fresh stream flow for desalination and restoration of the Tiligul estuary reservoir status. The stated approach to solving such an important and complex problem is up-todate and absolutely original, while maintaining its environmental rationality and energy-completeness. The approach and ploying on the marine surface of small salted waters of the Dnieper-Bug River in the area of the Tiligul estuary crucible allows them to be self-feeding in the estuary in volumes from 0.5 million $\mathrm{m}^{3} /$ day, which provides the possibility of controlling the hydro chemical state of the Tiligul estuary waters. It allows expecting the normalization of water salinity at the limit of $10 \%$ (with the presence of $28 \ldots 30 \%$ ), at least for the lower and middle part of the estuary, and the elimination of anaerobic "dead" zones in deep basins of the estuary. The construction and operation of locked channels in the thickness of the Tiligul estuary transshipment, equipped with powerful pumping units and fixed up with power from nearby wind farms (Rybakivske and Tuzlovsky wind fields), allow to realize as much as possible the most favorable for freshwater water supply the hydrological conditions that are formed by the runoff of the Dnipro-Bug estuary and the wind regime of the coastal marine area. It is possible to expect the normalization of the level of the Tiligul estuary within 3 to 5 years, the partial restoration of the saline-water regime of the waters and the elimination of the conditions for the emergence of thermohalklin in the deep water areas of its water area as a result of the implementation of the proposed design activities and the cut-off of reservoir degradation and sub-aquatic ecosystems.
\end{abstract}

Key words: North-Western Black Sea coast; Tiligul estuary; desalination of the estuary; hydro-chemistry of the Dnipro-Bug stream flow; closed estuaries.

Анотація. Стаття присвячена обгрунтуванню еколого-раціональних шляхів техногенного відновлення Тилігульського лиману, здатних припинити або суттєво зменшити загрозу сольового забруднення водойми. Тилігульський лиман є одним з найбільших лиманів Північного Причорномор'я, який в умовах кліматичних змін сучасності практично втратив здатність до самовідновлення водного балансу. Надмірна солоність лиману $є$ головною причиною виникнення та стійкого утримання термо- й галокліну, який зумовлює утворення безкисневих «мертвих» зон на глибинах більше 4 м. Проведено оцінювання рівня мінералізації морської води поблизу гирлової частини Тилігульського лиману за 2012-2019 рр. за виконання серії контролів, які враховували грубу глибинну структуру мінералізації та локально-прибережну специфіку розподілу Дніпровського стоку на фоні 
конкретної вітрової активності. Встановлено значно виражену сезонну й навіть добову мінливість показників мінералізації морської води поблизу пересипу Тилігульського лиману, що вказує на їх залежність від обсягів стоку Дніпро-Бузького лиману, напрямку вітрів і терморежиму прибережних вод. Результати еколого-гідрологічних досліджень дають можливість обгрунтувати й запропонувати часткове регульоване використання прісного стоку Дніпро-Бузького лиману для розпріснення та відновлення стану водойми Тилігульського лиману. Побудова та експлуатація шлюзованих каналів у товщі пересипу Тилігульського лиману, обладнаних потужними насосними установками і забезпечених живленням від поруч розташованих вітроелектростанцій, дають змогу сформувати найбільш сприятливі для прісноводного водозабезпечення гідрологічні умови. В результаті вжиття пропонованих проєктних заходів та припинення деградації водоймищних і навколоводоймищних екосистем можна очікувати впродовж 3-5 років нормалізацію рівня Тилігульського лиману, часткове відновлення солонуватоводного режиму вод та ліквідацію умов виникнення термо-галокліну у глибоководних ділянках його акваторії. Вказаний підхід до вирішення такої важливої та складної проблеми є новим і абсолютно оригінальним, а також зберігає свою екологічну раціональність та енергозавершеність.

Ключові слова: Північно-Західне Причорномор'я; Тилігульський лиман; розпріснення лиману; гідрохімія Дніпро-Бузького стоку; закриті лимани.

\section{ПОСТАНОВКА ЗАДАЧІ}

Однією $з$ найбільш характерних особливостей узбережжя Північно-Західного Причорномор'я є специфічні лиманні комплекси, які утворилися внаслідок затоплення річкових долин морем. «Класичним» представником таких лиманів $є$ Тилігульський, що є водоймою закритого типу до 82 км у довжину при ширині 0,2-3,5 км. Загальна площа водойми сягає майже 170 км$^{2}$, а загальна площа лиманного екокомплексу (разом із площами прибережних схилів) - 380 км². Площа водозбору становить 5240 км², середньорічний об'єм водойми в середині минулого століття оцінювали у 800 830 млн. м², але 3 кінця 80-х рр. більш реальні оцінки перебувають у межах 250-600 млн. м ${ }^{3}$ [1-3]. Уздовж берегів Тилігульського лиману ще збережені значні площі сухо-степових біотопів з відповідною біотою первинного типу. Природний комплекс долини лиману також зберігає високий рівень біорізноманіття, але його існуванню загрожують обміління та засолення вод лиману. Все це зумовлює необхідність вирішення першочергового завдання з винайдення шляхів відновлення гідроекосистеми лиману.

\section{АНАЛІЗ ОСТАННІХ ДОСЛІДЖЕНЬ І ПУБЛІКАЦІЙ}

До початку XIX століття лиман мав характер частково проточної водойми, забезпечений проходженням лиманних вод через мілкі та звивисті залишки гирлової ділянки (шириною від 4 до 6 км). Ïх повне замулення, а потім і перекриття пересипу штучним насипом траси Одеса - Миколаїв (із 1819 р.) практично унеможливили природний водообмін 3 морем, перетворивши лиман на закриту водойму. В окремі багатоводні роки мали місце неодноразові прориви пересипу в бік моря, спричинені скидом надмірних об'ємів води, але з 1959 р. по 1971 р. рівень лиману впав на 1,9 м, сягнувши загалом -2,3 м нижче від рівня моря [4].

Сучасні підходи до вирішення проблеми всихання лиману значною мірою обумовлені припиненням стоку річки Тилігул, що вказує на необхідність його відновлення для хоча б часткової стабілізації прісного балансу лиману. У реальності стік Тилігулу ніколи не забезпечував позитивного прісного балансу лиману, тому очевидно, що основою існування лиману завжди був виключно схиловий стік із площі водозбору. По мірі зменшення поверхневого стоку із 40 мм у середині ХХ сторіччя до 13 мм у 2010-2018 pp. (у межах водозбірної площі саме лиману), зумовленого зростанням посушливості клімату, негативний баланс водойми з початку 90-х рр. минулого сторіччя став стрімко збільшуватися.

Вказані явища не є новітніми, вони мають циклічний характер [5], ще у 1956-1959 рр. зумовили необхідність вжиття нагальних заходів щодо нормалізації стану лиману, реалізованих через побудову каналу для самоплинної подачі морської води. Згідно з різними оцінками щорічні об'єми подачі морської води у 1959-1968 рр. складали від 15-20\% до 30-35\% об'єму водойми, сягаючи в середньому 160 млн. м³/piк. Швидке заповнення каналу морськими заносами привело до його реконструкції та розширення у 1973 р., що зумовило збільшення подачі морської води до лиману у 1973-1981 рр. на рівні (без урахування сезонних варіацій) 1,0-1,5 млн. м³/добу. Поступово канал знову почав піддаватися піщаним заносам, отже, на початку 90-х рр. максимальні об'єми подачі морської води вже не перевищували 200-350 тис. м³/добу, а у 1995-2014 рр. лише 40-50 тис. $\mathrm{m}^{3} /$ добу [6]. За цих умов рівень лиману став інтенсивно зменшуватися, а влітку 2016 р. складав майже -1,9 м, загрожуючи самому існуванню цієї унікальної водойми.

\section{ВІДОКРЕМЛЕННЯ НЕ ВИРІШЕНИХ РАНІШЕ ЧАСТИН ЗАГАЛЬНОЇ ПРОБЛЕМИ}

Для стабілізації рівня водойми було вирішено провести реконструкцію каналу для подачі морської води, яка була розпочата у 2015 р. Закінчення реконструкції каналу та його відкриття у 2017 р. дали змогу 


\section{ТЕХНОЛОГІЇ ЗАХИСТУ НАВКОЛИШНЬОГО СЕРЕДОВИЩА № 1- 2019}

стабілізувати падіння рівня лиману, а потім підвищити його до показників початку 90-х рр. минулого сторіччя. Головною проблемою цього заходу є подача до лиману значних об'ємів солоної морської води, яка, випаровуючись із величезної площі, залишає у водоймі велику кількість солей.

\section{МЕТА ДОСЛІДЖЕННЯ}

Метою статті є обгрунтування еколого-раціональних шляхів техногенного відновлення Тилігульського лиману, здатних припинити або суттєво зменшити загрозу сольового забруднення водойми.

Загалом вибрана мета передбачає чіткі відповіді на низку таких ключових питань:

1) чи зможе зберегтися лиманна водойма без допомоги людини, в чому саме полягає така допомога;

2) чи можна за збереження водойми хоча б частково зменшити засоленість вод, відновивши ії малосолоноводний характер;

3) чи можна зберегти для розпріснення лиману запаси прісних вод, які поступають у багатоводні роки;

4) чи можна зменшити випаровуваність 3 поверхні лиману;

5) чи можна ліквідувати донні товщі детриту, які унеможливлюють кисневий баланс вод лиману.

Ці та інші питання $є$ взаємопов'язаними, а їх гострота й необхідність оперативного вирішення безперечні, отже, пошук шляхів їх вирішення має велике фундаментальне, прикладне та господарське значення.

\section{МЕТОДИ, ОБ'ЄКТ ТА ПРЕДМЕТ ДОСЛІДЖЕННЯ}

Об'єктом дослідження є процес відновлення Тилігульського лиману, а предметом дослідження - еколого-раціональні шляхи такого відновлення.

Базисним матеріалом для аналітичних узагальнень, результати яких покладені в основу статті, $є$ результати власних екологічних, гідрологічних, гідрохімічних та маршрутних досліджень, виконаних у 2012-2019 pр. на різних ділянках Тилігульського лиману й навколишніх територій. Крім того, як матеріали були використані літературні, звітні й статистичні дані щодо геоморфології, геології, гідрології, гідрохімії, палеокліматичної та сучасної кліматичної ситуації в Північно-Західному Причорномор’і. Поєднання ï з результатами власних досліджень дало змогу узагальнити дані щодо еколого-гідрологічних механізмів змін лиманних екокомплексів, оцінити сучасний стан водойми та розробити прогноз варіантів природного розвитку сукцесій на цій фазі трансформації лиманних біомів. Статистичні обчислення фактичних даних включали різноманітні методи параметричних і непараметричних розрахунків, поєднаних $з$ елементами кореляційного та системного аналізів на основі блоку стандартних програм пакета "Statistica" та операційної системи Microsoft Excel 2016.

\section{ОСНОВНИЙ МАТЕРІАЛ}

Аналіз літературних матеріалів і низки проєктних завдань, винесених на обговорення та конкурси, свідчить про те, що щодо збереження Тилігульського лиману як природної прісноводно-солонуватоводної водойми безальтернативною є вимога прісного водозабезпечення в об'ємі не менше 1 млн. м³/рік. Подібні об’єми могли бути забезпечені лише в системі реалізації проєкту «Дунай - Дніпро», який ще в середині 80-х рр. минулого сторіччя був визнаний екологічно несприйнятливим. Нині жодних джерел прісноводного водозабезпечення для Тилігульського лиману будьякими проєктами не пропонується, що спричинило безальтернативну подачу морської води для відновлення рівня лиману. На жаль, це перетворює лиман на величезний випарювальний басейн, який щорічно збільшує накопичення солі, до чого приводять висока вітрова активність у долині каньйонного типу та підвищення середньодобових літніх температур за умови малохмарності. Підвищену випаровуваність вод лиману зумовлює також каламутність води значно змілілої водойми, що приводить до швидкого прогрівання верхнього шару, але за збереження термо- й галокліну на межі лише 1,5-1,8 м.

Авторським проєктом, який опрацьовується у роботі, пропонується штучно-техногенний, але при цьому еколого-раціональний шлях відновлення стану водойми Тилігульського лиману за рахунок регульованої подачі опрісненого (5-9\%о) стоку Дніпро-Бузького лиману. Устя Дніпро-Бузького лиману розташовано від гирлової зони Тилігульського лиману на прямій відстані 24 км, отже, струмінь цього витоку, прямуючи вздовж «Одеського каналу», практично впирається в пересип Тилігульського лиману, а за негативного рівня останнього дає змогу самотоком подавати до нього поверхневі морські, відносно малосолоні води. Певною мірою південно-західному спрямуванню дніпровського стоку сприяє також Кільцева течія Чорного моря, яка переміщає значні об'єми щільних (за рахунок солоності та порівняно низьких температур) морських вод, забезпечуючи підпирання менш щільного й менш солоного річкового стоку на поверхні (в 3-10-метровому шарі) [7].

За дії несприятливих вітрів з південно-західного, південного й частково західного напрямків виникає вітровий нагін морських вод до устя Дніпро-Бузького лиману, що приводить до запирання річкових вод та підвищення його рівня до +1 м. Однак при цьому Дніпро-Бузький стік повністю не припиняється й продовжується в глибоководному режимі, що супроводжується зміщенням прісних вод у бік берега 3 їх подальшим виклинюванням на поверхню саме поблизу гирла Тилігульського лиману. Такі явища періодично повторюються, але вони порівняно короткочасні (до 3-5 діб поспіль), хоча взимку та навесні їх тривалість і потужність суттєво зростають [8]. 
Для оцінювання рівня мінералізації морської води поблизу гирлової частини Тилігульського лиману у 2012-2019 рр. були виконані серії контролів, які враховували грубу глибинну структуру мінералізації (відбори з поверхні, глибини 2 і 5 м) та локально-прибережну специфіку розподілу дніпровського стоку на фоні конкретної вітрової активності. Результати проведених досліджень та аналітичних узагальнень наведені в табл. 1.

Згідно 3 отриманими результатами контролів встановлено значно виражену сезонну й навіть добову мінливість показників мінералізації морської води поблизу пересипу Тилігульського лиману, що вказує на їх залежність від об'ємів стоку ДніпроБузького лиману, напрямку вітрів та терморежиму прибережних вод. При цьому встановлено переважання південно-західного напрямку в прибережній течії. Швидкість течії варіюється від 0,5 до 2,8 км/год. Із 29 випадків обліку наявності прибережної течії у двох випадках іiї не фіксували зовсім, а в трьох випадках установлено заміщення або нівелювання прибережної течії холодною глибинною течією з північною та північно-східною спрямованістю. Вказані напрямки не збігалися з наявними вітровими режимами, вказуючи на гало-термоклінальну природу глибинних течій, що підтверджується їх суто морським рівнем мінералізації на рівні 16,7-17,8\%.

Результати аналітичних узагальнень даних, відображених у табл. 1, показують стійкість солонувато- водної специфіки мінералізації вод локальної ділянки морської акваторії в зоні гирлової частини Тилігульського лиману, зумовлену впливом дніпровського стоку. Відповідно, наявна ситуація щодо гідрохімічних характеристик прибережних вод у зоні Тилігульського пересипу є сприятливою для побудови проєктів з використання малосолоного Дніпровсько-Бузького стоку для штучного розпріснення Тилігульського лиману.

Для деталізації ситуації, перевірки даних власних досліджень та їх порівняльного узагальнення використані офіційні дані порту «Південний» щодо рівня мінералізації морської води. Вказаний порт розташований на 17 км подалі в південно-західному напрямку від гирлової зони Тилігульського лиману. Дані щодо солоності вод є дуже важливими для диференціації суден та оцінювання їх загрузки, тому контролюються портовими службами по декілька разів на добу, що дає змогу здійснити їх детальний аналіз у різній кореляції з показниками вітрового й температурного режимів. Також були використані в порівняльному плані аналогічні показники щодо солоності вод Очаківського, Херсонського та Миколаївського річкових портів, які відображено даними табл. 2.

Наведені в табл. 1, 2 показники солоності води показують, що, незважаючи на періодичні вітрові нагони та термальнозалежну динаміку глибинної структури, води вздовж морського узбережжя (від Очакова до порту «Південний») загалом характеризуються порівняно низьким рівнем мінералізації. Солоність їх

Таблиця 1. Зональні та глибинні показники мінералізації (\%о) проб морської води поблизу пересипу Тилігульського лиману

\begin{tabular}{|c|c|c|c|c|c|c|c|c|c|}
\hline \multirow[b]{2}{*}{ Показники } & \multicolumn{3}{|c|}{$\begin{array}{c}\text { Морський берег } \\
\text { пересипу }\end{array}$} & \multicolumn{3}{|c|}{$\begin{array}{c}\text { У морі на відстані } 100 \text { м } \\
\text { від берега }\end{array}$} & \multicolumn{3}{|c|}{$\begin{array}{c}\text { У морі на відстані } \\
1 \text { км від берега }\end{array}$} \\
\hline & 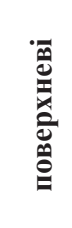 & 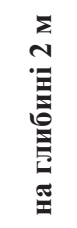 & 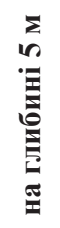 & 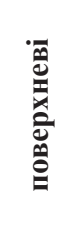 & 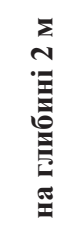 & 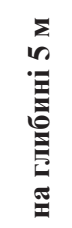 & 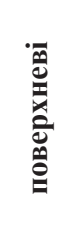 & 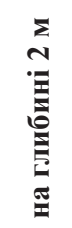 & 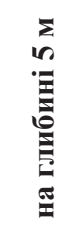 \\
\hline Максимальні & 17,1 & 17,5 & - & 16,4 & 17,0 & 17,7 & 16,4 & 17,0 & 17,7 \\
\hline Мінімальні & 5,7 & 6,2 & - & 5,3 & 5,2 & 10,8 & 5,0 & 5,0 & 11,1 \\
\hline Середні & 8,6 & 9,5 & - & 7,2 & 7,2 & 12,2 & 7,0 & 7,7 & 12,9 \\
\hline
\end{tabular}

Таблиця 2. Усереднені показники солоності (\%) води в акваторії Миколаївського, Херсонського й Очаківського річкових портів та морського порту «Південний»

\begin{tabular}{|c|c|c|c|c|c|c|c|c|c|c|c|}
\hline \multicolumn{9}{|c|}{ Річково-лиманні порти } & \multirow{2}{*}{\multicolumn{3}{|c|}{$\begin{array}{c}\text { Морський порт } \\
\text { «Південний» }\end{array}$}} \\
\hline \multicolumn{3}{|c|}{ Миколаївський («Ольвія») } & \multicolumn{3}{|c|}{ Херсонський } & \multicolumn{3}{|c|}{ Очаківський } & & & \\
\hline $\begin{array}{c}\text { макси- } \\
\text { мальний } \\
\text { показ- } \\
\text { ник }\end{array}$ & $\begin{array}{c}\text { міні- } \\
\text { мальний } \\
\text { показ- } \\
\text { ник }\end{array}$ & $\begin{array}{c}\text { середній } \\
\text { показ- } \\
\text { ник }\end{array}$ & $\begin{array}{c}\text { макси- } \\
\text { мальний } \\
\text { показ- } \\
\text { ник }\end{array}$ & $\begin{array}{c}\text { міні- } \\
\text { мальний } \\
\text { показ- } \\
\text { ник }\end{array}$ & $\begin{array}{c}\text { середній } \\
\text { показ- } \\
\text { ник }\end{array}$ & $\begin{array}{c}\text { макси- } \\
\text { мальний } \\
\text { показ- } \\
\text { ник }\end{array}$ & $\begin{array}{c}\text { міні- } \\
\text { мальний } \\
\text { показ- } \\
\text { ник }\end{array}$ & $\begin{array}{c}\text { середній } \\
\text { показ- } \\
\text { ник }\end{array}$ & $\begin{array}{c}\text { макси- } \\
\text { мальний } \\
\text { показ- } \\
\text { ник }\end{array}$ & $\begin{array}{c}\text { міні- } \\
\text { мальний } \\
\text { показ- } \\
\text { ник }\end{array}$ & $\begin{array}{c}\text { середній } \\
\text { показ- } \\
\text { ник }\end{array}$ \\
\hline 13,1 & 3,3 & 6,0 & 9,0 & 2,1 & 2,9 & 17,2 & 3,5 & 8,1 & 17,6 & 5,3 & 12,7 \\
\hline
\end{tabular}




\section{ТЕХНОЛОГІЇ ЗАХИСТУ НАВКОЛИШНЬОГО СЕРЕДОВИЩА № 1 - 2019}

коливається в межах від 5\%о до 14,5\%о у поверхневих та від 7,8\% до 17,9\%о у глибинних шарах.

Загалом у 2012-2019 рр. у середньому за рік $262 \pm 12$ діб солоність поверхневих прибережних вод не перевищувала $10 \%$, а лише $37 \pm 9$ діб вона була нижче 8\%. В окремі дні й навіть години за різких відгонних вітрів північних напрямків показники мінералізації прибережних вод сягали 3,3-4,2\%о, а за даними Очаківського порту в ці дні рівень у створі Дніпро-Бузького лиману падав майже до -1,0 м. Упродовж року в середньому висока солоність вод (на межі 10,5-15,0\%) утримувалася $79 \pm 11$ діб, а солоність морського рівня (на межі 16,2-17,9\%о) - лише впродовж $25 \pm 6$ діб. Подібні відгінно-нагонні явища характерні для всього Північно-Західного узбережжя й супроводжуються динамічним станом прибережної морської акваторії.

Зазначені характеристики динаміки рівня й солоності вод морського узбережжя поблизу пересипу Тилігульського лиману, безперечно, мають прямий вплив на гідрохімічні параметри та об'єми проникнення в лиман морської води, яка перетікає через наявний у пересипі канал. Зрозуміло, що навіть тимчасове зростання рівня прибережних вод зумовлює їх посилене проникнення в лиман, що одночасно супроводжується занесенням більш солоних морських вод, іноді з високим вмістом «морського» сірководню. Вітрові перепади рівня малосолоних вод здебільшого не сприяють їх перетіканню з моря в лиман.

Останне вимагає побудови на каналі спеціальних регулюючих гідротехнічних споруд (рис. 1), які б дали змогу свідомо, залежно від реального гідрохімічного стану прибережних вод, вибірково перепускати у лиман малосолоні води та припиняти притік солоних морських вод.

\section{ОБГОВОРЕННЯ ОТРИМАНИХ РЕЗУЛЬТАТІВ}

Отже, запропонована регуляція за допомогою гідротехнічних споруд дала змогу хоча б частково обмежити темпи засоленості лиману за рахунок морської води та успішно використати можливість розпріснення водойми за рахунок паводкових вод. За наявних умов прісні паводкові води навіть у найбільш сприятливі роки (наприклад, у 2003 та 2012 рр.) [9] замість розпріснення лиману просто розтікаються за його поверхнею i, не змішуючись із щільними солоними водами, стікають у море.

Загалом проєкт використання штучної подачі 3 моря у Тилігульський лиман малосолоних вод Дніпро-Бузького лиману $[10 ; 11]$ базується на шлюзуванні наявного каналу, забезпечуючи пропуск із моря у лиман лише малосолоних вод 3 мінералізацією 4-7\%. Це в середньорічному об'ємі морського водопостачання дає змогу розрахунково зменшити потрапляння в лиман солей на 35-40\% від сьогоденного об'єму. абсолютних показниках це майже 100 тис. т солей, переважно хлоридів натрію та магнію.

Не менш важливим наслідком шлюзування каналу «море - лиман» є можливість утримання прісних паводкових вод у лимані за перекривання їм стоку в море. Подібні накопичення прісноводного стоку річки Тилігул та поверхневого стоку з водозбірної площі виникають раз на 5-9 років і здатні суттєво покращити стан вод лиману.

\section{ВИСНОВКИ}

На основі проведеного дослідження можна зробити такі висновки.

1) Підхід та виклинювання на морську поверхню малосолоних вод Дніпро-Бузького стоку в районі пересипу Тилігульського лиману дають змогу здійснити їх самотічну подачу в лиман в об'ємах від 0,5

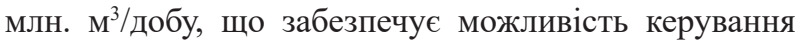
гідрохімічним станом вод Тилігульського лиману. Це дає змогу очікувати принаймні для нижньої та середньої частин лиману нормалізацію солоності вод на межі до 10\%о (за наявних 28-30\%о) і ліквідацію анаеробних «мертвих» зон у глибоких котловинах лиману.
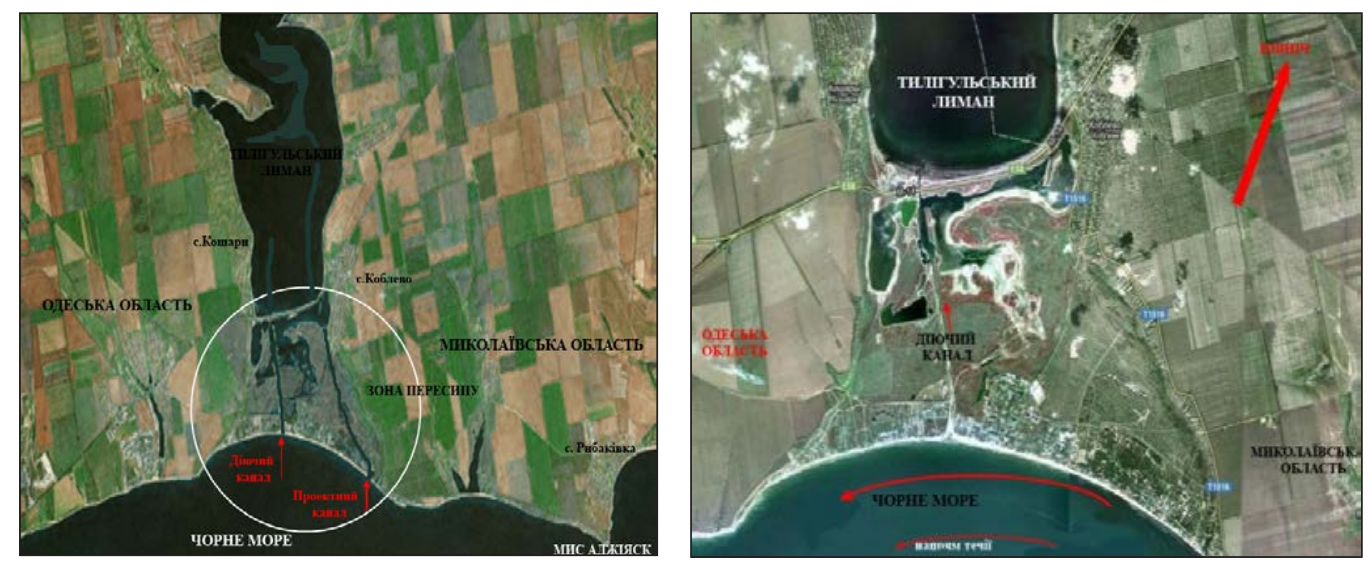

Рис. 1. Розташування трас наявного (а) та проєктного каналів (б) зі шлюзовими входами на морській стороні пересипу Тилігульського лиману 
2) Побудова та експлуатація шлюзованих каналів у товщі пересипу Тилігульського лиману, обладнаних потужними насосними установками й забезпечених живленням від поруч розташованих вітроелектростанцій (Рибаківське та Тузловське вітрові поля), дають змогу максимально реалізувати найбільш сприятливі для прісноводного водозабезпечення гідрологічні умови, які формуються стоком Дніпро-Бузького лиману й вітровим режимом прибережно-морської акваторії.

3) В результаті вжиття пропонованих проєктних заходів та припинення деградації водоймищ- них і навколоводоймищних екосистем можна очікувати впродовж 3-5 років нормалізацію рівня Тилігульського лиману, часткове відновлення солонуватоводного режиму вод та ліквідацію умов виникнення термо-галокліну в глибоководних ділянках його акваторії.

Перспективи подальших досліджень полягають у технічно-екологічному відпрацюванні проєктних заходів та розробленні детальних, еколого-раціональних підходів до оптимальних гідрологічних засад стабілізації стану водоймищних екосистем Тилігульського лиману.

\section{REFERENCES}

[1] Geologiya shel'fa USSR. Limany (1984). [Geology of the shelf of USSR. Estuaries]. Kiev: Naukova dumka.

[2] Kaplin, P.A., \& Porotov, A.V. (2012). Izmeneniya klimata v pozdnem golotsene i razvitie morskikh beregov Chernogo morya [Climate change in the Late Holocene and the development of the Black Sea coast]. Geomorfologiya, 4, 64-72.

[3] Konikov, E.G. (2013). Geologicheskaya istoriya ust'evoy chasti Tiligul'skogo limana v pozdnem pleystotsene - golotsene. [Geological history of the estuary of the Tiligul estuary in the Late Pleistocene - Holocene]. Geology and Minerals of the World Ocean, 2 (32), 76-86.

[4] Tuchkovenko, Yu.S. et all. (2011). Sovremennyy gidrologicheskiy rezhim i dinamika vod Tiligul'skogo limana [Modern hydrological regime and dynamics of waters of the Tiligul estuary]. Ukrainian Hydrometeorological Journal, 9, $192-209$.

[5] Nakonechnyi, I.V., \& Danylenko, V.L. (2014). Ekoloho-hidrolohichni ta hidrokhimichni chynnyky tsyklichnykh suktsesii vodnykh ekosystem Tylihulskoho lymanu [Ecological-hydrological and hydrochemical factors of cyclic successions of water ecosystems of the Tiligul estuary]. Agroecological journal, 4, 16-22.

[6] Gopchenko, E.D., \& Loboda, N.S. (2005). Vodnye resursy Severo-Zapadnogo Prichernomor'ya ( $v$ estestvennykh $i$ narushennykh khozyaystvennoy deyatel'nost'yu usloviyakh) [Water resources of the North-Western Black Sea region (in natural and disturbed economic conditions)]. Kiev: KNT.

[7] Zaytsev, Yu.P., Aleksandrov, B.G., \& Minicheva, G.G. (2006). Severo-Zapadnaya chast' Chernogo morya: biologiya $i$ ekologiya [North-West of the Black Sea: Biology and Ecology]. Kiev: Naukova dumka.

[8] Khmara, T.V., Tuchkovenko, Yu.S., \& Slepchuk, K.A. (2012). Proniknovenie solenykh morskikh vod v priust'evye oblasti rek Dnepr i Yuzhnyy Bug [Penetration of salty sea water in the littoral regions of the rivers Dnipro and Southern Bug]. Proceedings of the Lymany Pivnichno-Zakhidnoho Prychornomoria: actual hydroecological problems and ways of their solution (Odessa, February 12-14, 2012). Odessa: Odessa State Environmental University, 134-137.

[9] Loboda, N.S. (2012). Otsenka pritoka presnykh vod v Tiligul'skiy liman [Estimation of fresh water inflow into Tiligul estuary]. Aktual'nye problemy limanov Severo-Zapadnogo Prichernomor'ya [Actual problems of estuaries of the northwestern Black Sea coast]. Odessa: TES, 140-148.

[10] Zhuravleva, L.A. (1988). Gidrokhimiya ust'evoy oblasti Dnepra i Yuzhnogo Buga v usloviyakh zaregulirovaniya rechnogo stoka [Hydrochemistry of the mouth area of the Dnieper and the Southern Bug under conditions of regulation of river flow]. Kiev: Naukova dumka.

[11] Shuyskiy, Yu.D., \& Stoyan, A.A. (2011). Opyt i analiz rezul'tatov antropogennoy perestroyki estestvennogo limana na severo-zapadnom poberezh'e Chernogo morya [Experience and analysis of the results of anthropogenic restructuring of the natural estuary on the northwest coast of the Black Sea]. Ecological safety of coastal and shelf zones and comprehensive use of shelf resources, 26, 97-109.

\section{СПИСОК ВИКОРИСТАНОЇ ЛІТЕРАТУРИ}

[1] Геология шельфа УССР. Лиманы. Киев : Научная мысль, 1984.

[2] Каплин П.А., Поротов, А.В. Изменения климата в позднем голоцене и развитие морских берегов Черного моря. Геоморфология. 2012. № 4. С. 64-72.

[3] Коников Е.Г. Геологическая история устьевой части Тилигульского лимана в позднем плейстоцене - голоцене. Геология и полезные ископаемые мирового океана. 2013. № 2 (32). С. 76-86.

[4] Тучковенко Ю.С. и др. Современный гидрологический режим и динамика вод Тилигульского лимана. Украӥнський гідрометеорологічний журнал. 2011. № 9. С. 192-209.

[5] Наконечний І.В., Даниленко В.Л. Еколого-гідрологічні та гідрохімічні чинники циклічних сукцесій водних екосистем Тилігульського лиману. Агроекологічний журнал. 2014. № 4. С. 16-22.

[6] Гопченко Е.Д., Лобода Н.С. Водные ресурсы Северо-Западного Причерноморья (в естественных и нарушенных хозяйственной деятельностью условиях). Киев : КНТ, 2005.

[7] Зайцев Ю.П., Александров Б.Г., Миничева Г.Г. Северо-Западная часть Черного моря: биология и экология. Киев : Научная мысль, 2006. 


\section{ТЕХНОЛОГІЇ ЗАХИСТУ НАВКОЛИШНЬОГО СЕРЕДОВИЩА № 1 व 2019}

[8] Хмара Т.В., Тучковенко Ю.С., Слепчук К.А. Проникновение соленых морских вод в приустьевые области рек Днепр и Южный Буг. Лимани Північно-Західного Причорномор'я: актуальні гідроекологічні проблеми та шляхи їх вирішення (Одесса, Февраль, 12-14, 2012). Одеса, 2012. С. 134-137.

[9] Лобода Н.С. Оценка притока пресных вод в Тилигульский лиман. Актуальные проблемыл лиманов Северо-Западного Причерноморья. Одесса : ТЭС, 2012. С. 140-148.

[10] Журавлева Л.А. Гидрохимия устьевой области Днепра и Южного Буга в условиях зарегулирования речного стока. Киев : Научная мысль, 1988.

[11] Шуйский Ю.Д., Стоян А.А. Опыт и анализ результатов антропогенной перестройки естественного лимана на северо-западном побережье Черного моря. Экологическая безопасность прибрежной и шельфовой зон и комплексное использование ресурсов шельфа. 2011. № 26. С. 97-109. 